\title{
CRTM-2: Maize with Effective Tillering Trait
}

\author{
N. Jyothi Lakshmi*, P. Raghuram Reddy, Amol Patil, M. Vanaja, \\ K. Salini, B. Sarkar, S.S. Shishodia, S.K. Yadav, V. Maruthi, \\ M. Maheswari, K. Sammi Reddy and G. Ravindra Chary
}

Central Research Institute for Dryland Agriculture, Santhoshnagar, Hyderabad, India

*Corresponding author

\section{Keywords}

Tillering maize, Zea

luxuriance, Zea

mays, Effective

tillers, Effective

Dendrogram

Article Info

Accepted:

12 April 2019

Available Online:

10 May 2019 cobs, SSR primers,

\section{A B S T R A C T}

Maize genotypes with effective tillers from a natural mutant with ineffective tillers are being developed at Central Research Institute for Dryland Agriculture, Hyderabad, India. Teosinte (Zea mays ssp. luxurians) and maize (Zea mays ssp. mays) cultivars - African tall (fodder maize) and harsha (composite) were included for development of CRIDA tillering maize. CRTM-2 had five effective tillers similar to teosinte, with a total height of 1223.5 $\mathrm{cm}, 62.0$ leaves and 25.8 filled cobs for the single plant. CRTM-2 showed an increase of $530.3,423.7$ and $2086.0 \%$ over the varietal check/parent harsha while the increase was 388.0, 315.8 and $2350 \%$ over check /parent African tall and increase was 15.5, 34.1 and $53.0 \%$ over check/parent teosinte, for plant height, number of leaves and number of filled cobs respectively averaged over four seasons viz; 2016 (kharif and rabi), 2017 kharif and 2018 kharif. CRTM-2 had tillers like teosinte and the shape of cobs and seed type of Zea mays ssp. mays. Six SSR primers were employed for understanding the similarity between CRTM-2 and its parents. The dendrogram showed that CRTM-2 formed cluster with teosinte, African tall and harsha indicating that these are the parents which introgressed in the development of CRTM-2. This tillering maize can be source material for innovative concept of developing new tillering maize varieties with effective cobs and significantly higher productivity and production of feed, fodder and food for animals, poultry and humans apart from industrial uses.

\section{Introduction}

Maize (Zea mays L.) is one of the most important crops in the world, being among the primary sources of human food, animal feed, and raw material for some industrial processes. Maize has wider adaptability under varied agro-climatic conditions. Wild species are important sources of genetic variability and may be exploited by breeding programs to introgress desirable traits. The potential use of teosinte in maize breeding has been evaluated since 1950s. Researchers concluded that teosinte is a valuable germplasm for maize improvement, providing resistance to diseases and other abiotic stresses (Reeves, 1950), as well as quantitative traits (Cohen and Galinat, 1984; Casas et al., 2001). Some 
of the ancestral maize species have the prolificacy characteristics. Recently their architecture related to particular traits has been elucidated (Weber et al., 2008). Such studies suggested the relationship between specific gene and trait variation in teosinte.

The annual teosinte, Zea mays ssp.luxurians, has tillering ability, having 6-7 tillers with tender stem, many small leaves and many very small cobs. It is highly palatable to the animals with high nutritive value. However the seeds are very hard, small sized and bitter in taste and low yielding. African tall is a tall, single stemmed, many leafed with white seeded cob and matures in 130-135 days. It produces higher green fodder yield and good silage can also be prepared from it. Maize composite variety harsha is yellow-orange seeded, drought tolerant, high yielding and matures in 100-110 days.

Present study was aimed to develop tillering maize using teosinte, African tall and harsha, having more no. of tillers with effective cobs, more no. of leaves/plant and cobs with effective seeds for higher productivity of fodder and seed.

\section{Materials and Methods}

A natural mutant with tillers was first identified in Hayathnagar Research Farm of CRIDA, Hyderabad during 1990s. It had ineffective tillers (tillers without cobs). To improve the number of effective tillers it was crossed with teosinte. The progeny of mutant and teosinte was crossed with African tall to improve tiller height. The above crossing with teosinte and African tall, using them as male parent was done in alternate seasons. After 4 years of above crossing these were again crossed with normal maize (compositeharsha) to attain the effective cob size as well as normal maize seed. This was followed by recurrent selection, back cross breeding, selfing, half sib, full sib followed by pedigree breeding method and selection in each season to identify plants with desirable characteristics of higher number of tillers, tillers with effective cobs and normal maize type seed. CRTM-2 developed by above procedure had five effective tillers, filled cobs and normal maize seeds.

The crop was sown in Kharif season during June month in 2016, 2017 and 2018 and rabi season during November 2016. Teosinte, African tall and harsha were sown along with CRTM-2 in all the seasons. The spacing was $75 \times 30 \mathrm{~cm}$ between rows and within a row respectively. Recommended dose of fertilizer for maize at the rate of 120:60:60 kg/ha of $\mathrm{N}$, $\mathrm{P}_{2} \mathrm{O}_{5}$ and $\mathrm{K}_{2} \mathrm{O}$ was applied to the crop. Crop was maintained free from moisture stress, pests and diseases. Crop was grown in 3 replications. Each replication had 2 rows of 5 meter length. Crop duration of CRTM-2 was about 105-110 days. The checks harsha and African tall matured in 110 and 135 days respectively.

\section{DNA isolation, PCR amplification, SSR data analysis and clustering}

For DNA isolation, leaf samples were collected from 4 week old plants of CRTM-2 (main stem and all five tillers separately), teosinte (leaves of main stem and tillers were mixed), African tall and harsha and genomic DNA was extracted and purified following CTAB protocol (Doyle and Doyle, 1990) with minor modification. Six SSR loci, mostly possessing a repeat unit greater than two nucleotides ranging from 1.02 to 7.06 bins on the chromosome were obtained from maize genetics and genomic data base official website (https://www.maizegdb.org). The selected SSR primers were bnlg 490, bnlg 589, bnlg 1178, bnlg 1346 phi 116 and umc 1546. DNA amplification was carried in $20 \mu \mathrm{l}$ reaction mixture containing 50ng of genomic 
DNA (Murray and Thompson 1980), 19, $1 \mu \mathrm{l}$ of each forward and reverse primer $(10 \mu \mathrm{M} /$ $\mu \mathrm{l}), 0.5 \mu \mathrm{l}$ DNTPs $(20 \mathrm{mM} / \mu 1), 3.6 \mu \mathrm{l}$ of $10 \mathrm{X}$ buffer with $2.5 \mathrm{mM} \mathrm{MgCl}$, 1 unit of Taq polymerace $(5 \mathrm{U} / \mu \mathrm{l})$ and made up the final volume to $20 \mu \mathrm{l}$ with double distill water. Reaction mixture were thermal cycled at $94^{\circ} \mathrm{C}$ for $5 \mathrm{~min}$. followed by 35 cycles at $94{ }^{\circ} \mathrm{C}$ for $45 \mathrm{sec}$., $54-56{ }^{\circ} \mathrm{C}$ for $30 \mathrm{sec}$. and $72{ }^{\circ} \mathrm{C}$ for 45 sec. with final extension with same temperature for $9 \mathrm{~min}$. followed by $4{ }^{\circ} \mathrm{C}$ to preserve the product. The amplified product was resolved on $3 \%(\mathrm{w} / \mathrm{v})$ agarose gel in $1 \mathrm{X}$ TAE buffer with $1 \% \mathrm{EtBr}$ at $70 \mathrm{~V}$ for $1 \mathrm{hr}$ along with $50 \mathrm{bp}$ ladder. Gel documentation was done with help of Biorad Gel Doc ${ }^{\mathrm{TM}} \mathrm{XR}^{+}$ system.

The banding pattern of main stem and all five tillers was similar for each primer. Hence banding pattern of main stem and only two tillers were shown in Figure 2 and the same was used for scoring and analysis.

\section{Scoring and analysis}

Bands generated in CTRM-2 main stem, tiller 1, tiller 2 and parents using six ssr primers were analyzed by assigning 1 or 0 depending on the presence or absence of each allele form. Data was scored individually and then combined for final UPGMA and complete linkage cluster analysis. Distances between genotypes were calculated by Jaccard similarity coefficient (Jaccard, 1901). The tree files were generated by DARwin Version 5.0.158 software (Perrier et al., 2003)

\section{Results and Discussion}

The unique characters of CRTM-2, tillering maize developed at CRIDA are presented in table 1 along with checks/parents viz., teosinte, maize variety African tall and harsha for the years 2016 kharif, 2016 rabi, 2017 kharif and 2018 kharif and picture 1. The tillering maize, CRTM-2 has unique trait viz., high number of effective tillers/plant. These tillers have effective cobs and seeds. CRTM-2 recorded five effective tall tillers apart from main stem and high number of leaves and filled cobs. The mean data over four seasons are given in table 1. CRTM-2 showed an average height of $249.8 \mathrm{~cm}$ for main stem with a range of $161.5 \mathrm{~cm}$ to $234.3 \mathrm{~cm}$ in the height of five tillers. The total height of main stem and 5 tillers put together was $1223.5 \mathrm{~cm}$ while the checks teosinte, African tall and harsha recorded 1057.0, 250.3 and $194.8 \mathrm{~cm}$ respectively. The average no. of leaves was 11.3 on main plant with a range of 9.8 to 10.5 in five tillers. The total no. of leaves per plant was 62.0 while for checks it was 46.3, 15.0 and 11.9 for teosinte, African tall and harsha respectively. The average no. of filled cobs on the main plant was 5.8 in CRTM-2, while for the five tillers it ranged from 2.8-5.0 numbers with total no. of filled cobs for single plant being 25.8 while the checks teosinte, African tall and harsha recorded 55.0, 1.1 and 1.2 respectively.

The variability analysis revealed CRTM-2 was significantly different from teosinte, African tall and harsha for all the characters studied (Table 2). CRTM-2 showed similar no. of tillers as that of teosinte but had effective tillers with effective cobs and seed though the total no. of cobs was lower. It is interesting to note at this stage that the cobs of teosinte are too small in size while CRTM-2 had significantly bigger size of cobs both in length and width. CRTM-2 had seeds similar to maize (Picture 1). CRTM-2 was also significantly superior to teosinte, African tall and harsha for total plant height and number of leaves.

The percentage of superiority of CRTM-2 over teosinte, African tall and harsha for plant height was 15.5, 388.0 and $530.3 \%$ averaged over 4 seasons (Fig. 1). 
Table.1 Data on number of tillers, height, number of leaves and number of filled cobs of main plant and tillers in CRTM-2 and Checks (parents) viz., teosinte, variety harsha and African tall for four seasons viz. 2016k 2016R, 2017k and 2018k

\begin{tabular}{|c|c|c|c|c|c|c|c|c|c|c|c|c|c|c|c|}
\hline CRTM-2 & \multicolumn{5}{|c|}{ Height $(\mathbf{c m})$} & \multicolumn{5}{|c|}{ No. of leaves } & \multicolumn{5}{|c|}{ No. of filled cobs } \\
\hline $\begin{array}{l}\text { Main stem } \\
\text { /Tiller }\end{array}$ & $\begin{array}{c}2016 \\
\mathrm{~K}\end{array}$ & $\begin{array}{c}2016 \\
\mathrm{R}\end{array}$ & 2017 & $\begin{array}{c}2018 \\
\mathrm{~K}\end{array}$ & Mean & $2016 K$ & $\begin{array}{c}2016 \\
\mathrm{R}\end{array}$ & $\begin{array}{c}2017 \\
\mathrm{~K}\end{array}$ & $\begin{array}{c}2018 \\
\mathrm{~K}\end{array}$ & Mean & $\begin{array}{c}201 \\
6 \\
K\end{array}$ & $\begin{array}{c}201 \\
6 \\
\mathrm{R}\end{array}$ & $\begin{array}{c}201 \\
7 \mathrm{~K}\end{array}$ & $\begin{array}{l}201 \\
8 \mathrm{~K}\end{array}$ & $\begin{array}{l}\text { Mea } \\
\text { n }\end{array}$ \\
\hline Main stem & 247 & 233 & 257 & 262 & 249.8 & 10 & 12 & 12 & 11 & 11.3 & 6 & 5 & 5 & 7 & 5.8 \\
\hline Tiller 1 & 217 & 231 & 241 & 248 & 234.3 & 10 & 10 & 11 & 11 & 10.5 & 4 & 3 & 8 & 5 & 5.0 \\
\hline Tiller 2 & 187 & 206 & 225 & 223 & 208.5 & 10 & 10 & 11 & 10 & 10.3 & 3 & 3 & 7 & 7 & 5.0 \\
\hline Tiller 3 & 180 & 175 & 210 & 215 & 196.8 & 10 & 10 & 11 & 10 & 10.3 & 3 & 5 & 3 & 3 & 3.5 \\
\hline Tiller 4 & 125 & 168 & 200 & 198 & 172.8 & 10 & 10 & 10 & 10 & 10.0 & 3 & 3 & 5 & 4 & 3.8 \\
\hline Tiller 5 & 109 & 155 & 192 & 190 & 161.5 & 10 & 10 & 9 & 10 & 9.8 & 1 & 2 & 4 & 4 & 2.8 \\
\hline Total & 1065 & 1168 & 1325 & 1336 & 1223.5 & 60 & 62 & 64 & 62 & 62.0 & 20 & 21 & 32 & 30 & 25.8 \\
\hline \multicolumn{16}{|c|}{ Checks/parents } \\
\hline \multicolumn{16}{|l|}{ Teosinte } \\
\hline Main stem & 185 & 192 & 195 & 202 & 193.5 & 8 & 8 & 8 & 8 & 8.0 & 22 & 20 & 21 & 24 & 21.8 \\
\hline Tiller 1 & 180 & 187 & 190 & 197 & 188.5 & 8 & 8 & 8 & 8 & 8.0 & 7 & 7 & 7 & 7 & 7.0 \\
\hline Tiller 2 & 175 & 189 & 190 & 192 & 186.5 & 8 & 8 & 8 & 8 & 8.0 & 7 & 7 & 7 & 7 & 7.0 \\
\hline Tiller 3 & 169 & 181 & 180 & 186 & 179.0 & 8 & 7 & 8 & 8 & 7.8 & 7 & 7 & 7 & 7 & 7.0 \\
\hline Tiller 4 & 152 & 159 & 165 & 175 & 162.8 & 7 & 7 & 7 & 8 & 7.3 & 6 & 6 & 6 & 6 & 6.0 \\
\hline Tiller 5 & 143 & 146 & 142 & 157 & 147.0 & 7 & 7 & 7 & 8 & 7.3 & 6 & 6 & 6 & 6 & 6.0 \\
\hline Total & 1004 & 1054 & 1062 & 1109 & 1057.3 & 46 & 45 & 46 & 48 & 46.3 & 55 & 53 & 54 & 57 & 54.8 \\
\hline African tall & 233 & 243 & 255 & 270 & 250.3 & 15.5 & 15.5 & 14 & 14.8 & 15.0 & 1 & 1 & 1 & 1.2 & 1.1 \\
\hline Harsha & 175 & 176.5 & 197.8 & 230 & 194.8 & 11 & 11 & 13.3 & 12.2 & 11.9 & 1.2 & 1.3 & 1.3 & 1 & 1.2 \\
\hline \multicolumn{16}{|c|}{ \% inc. or dec. of CRTM-2 over } \\
\hline Teosinte & 6.1 & 10.8 & 24.8 & 20.5 & 15.5 & 30.4 & 37.8 & 39.1 & 29.2 & 34.1 & -63.6 & -60.4 & -40.7 & -47.4 & -53.0 \\
\hline African tall & 357.1 & 380.7 & 419.6 & 394.8 & 388.0 & 287.1 & 300.0 & 357.1 & 318.9 & 315.8 & 1900 & 2000 & 3100 & 2400 & 2350 \\
\hline Harsha & 508.6 & 561.8 & 569.9 & 480.9 & 530.3 & 445.5 & 416.7 & 424.6 & 408.2 & 423.7 & 1567 & 1515 & 2362 & 2900 & 2086 \\
\hline
\end{tabular}


Table.2 Variability in No. of tillers, total plant height, No. of leaves and No. of cobs per plant in CRTM-2 and checks/parents, teosinte, harsha and African tall over mean data of four seasons viz., 2016k, 2016R, 2017k and 2018k

\begin{tabular}{|c|c|c|c|c|}
\hline \multirow{2}{*}{ Genotypes } & \multicolumn{4}{|c|}{ Parameters } \\
\cline { 2 - 5 } & $\begin{array}{c}\text { No. of } \\
\text { tillers }\end{array}$ & Height $(\mathbf{c m})$ & No. of leaves & $\begin{array}{c}\text { No. of filled } \\
\text { cobs }\end{array}$ \\
\hline CRTM-2 & 5 & $1223.5 \mathrm{a}$ & $62.0 \mathrm{a}$ & $25.8 \mathrm{a}$ \\
\hline Teosinte & 5 & $1057.3 \mathrm{~b}$ & $47.3 \mathrm{~b}$ & $55.0 \mathrm{~b}$ \\
\hline African tall & - & $250.3 \mathrm{c}$ & $15.0 \mathrm{c}$ & $1.1 \mathrm{c}$ \\
\hline Harsha & - & $194.8 \mathrm{c}$ & $11.9 \mathrm{~d}$ & $1.2 \mathrm{c}$ \\
\hline
\end{tabular}

Note: values followed by the same letter in a column are not significantly different at $\mathrm{P}=0.01$.

Fig.1 Percentage increase or decrease of CRTM-2 over teosinte, African tall and harsha for plant height, no. of leaves and no. of cobs per plant (mean of four seasons)

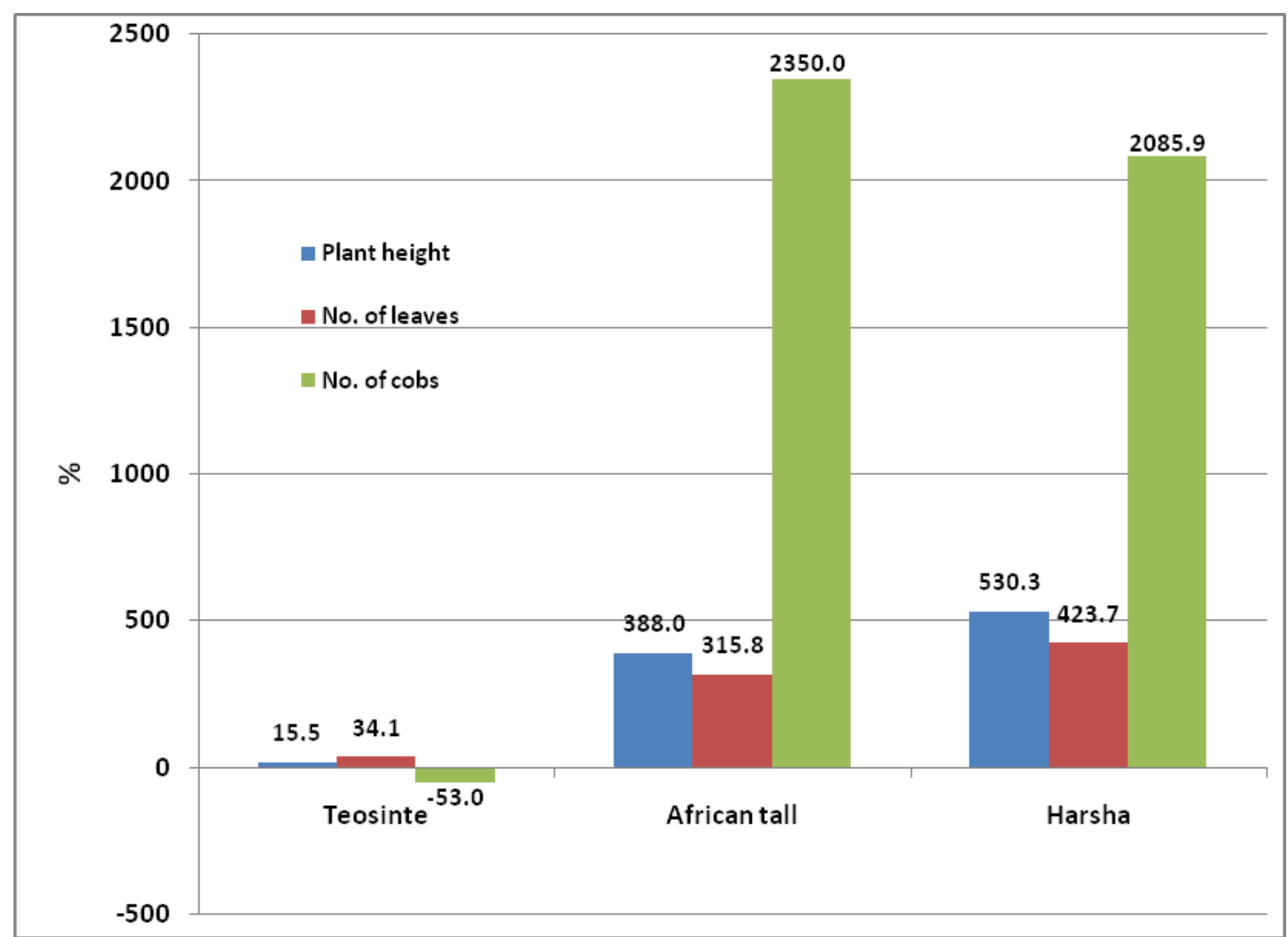


Fig.2 PCR amplification profile of checks/parents (teosinte, African tall and harsha) and CRTM2 obtained with bnlg 490, bnlg 1346, bnlg 589, bnlg 1178, phi 116, umc1546 ssr primers
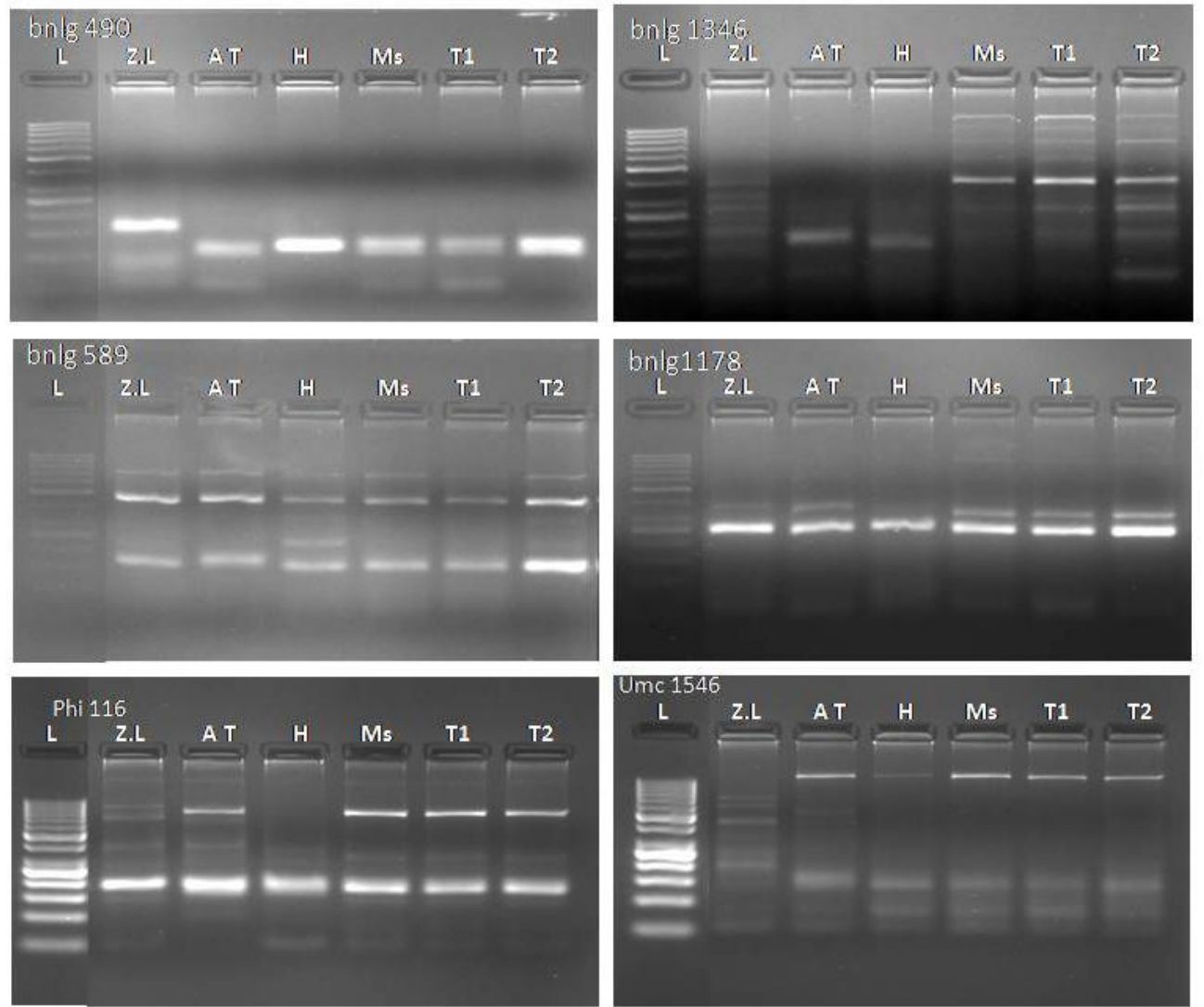

L-DNA ladder, Z.L-Zea Luxuriance, AT-African tall, H-Harsha, Ms-main stem, T1- Tiller 1, T2- Tiller 2 of tillering maize

Fig.3 Dendrogram based on SSR data of CRTM-1 (main stem (MS), tiller 1 (T1) and tiller 2 (T2)) and its parents - teosinte (Zea luxuriance), African tall (AT) and harsha (H)

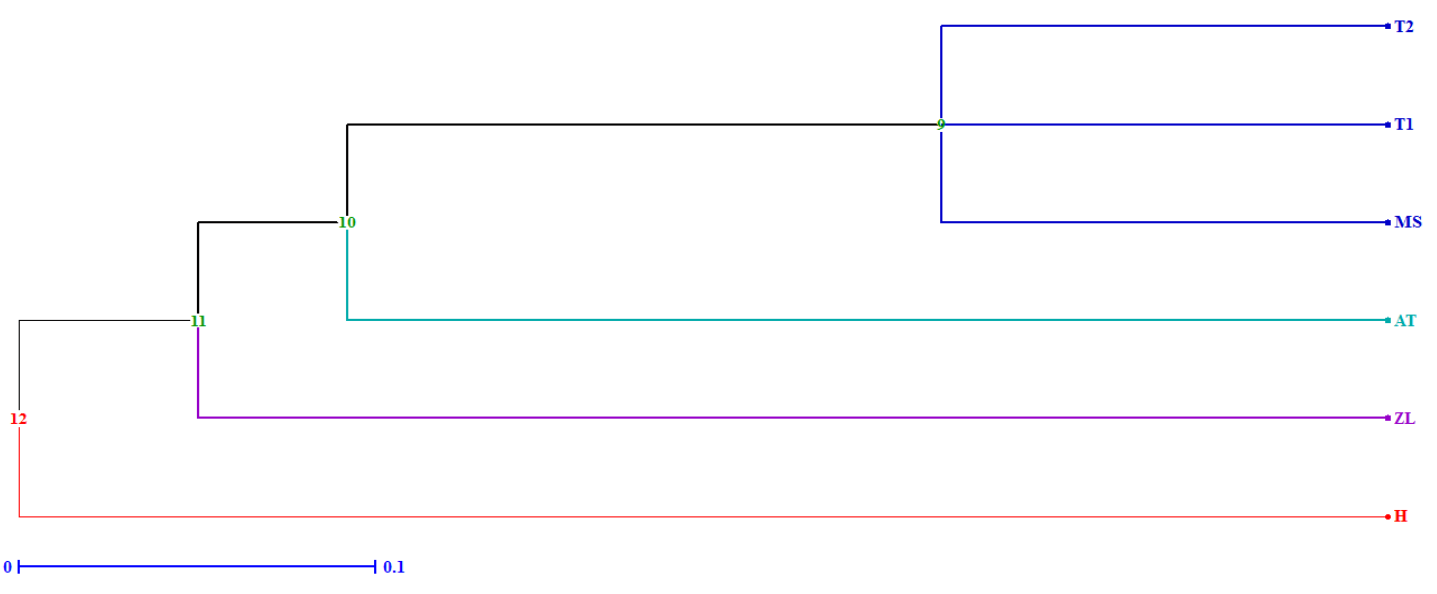


Pic.1 Photos showing the tillers, cobs and seeds of teosinte and tillering maize, CRTM-2
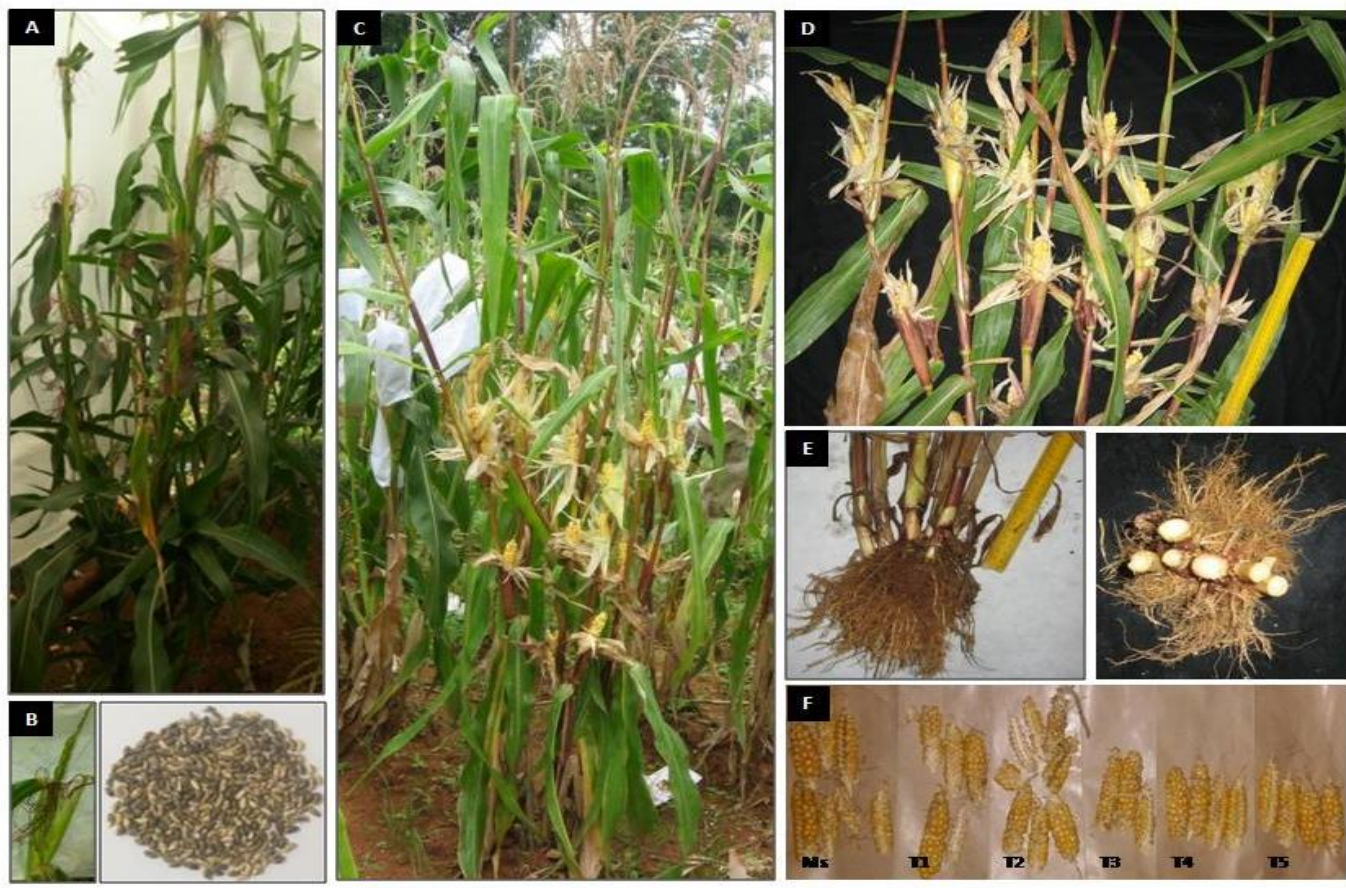

A) Teosinte plant, B) Ear and seeds of teosinte, C) Tillering maize, CRTM-2, D) Cobs on main stem and tillers of CRTM-2, E) Root of CRTM-2, F) Seeds on cobs of main stem (ms) and 5 tillers of CRTM-2.

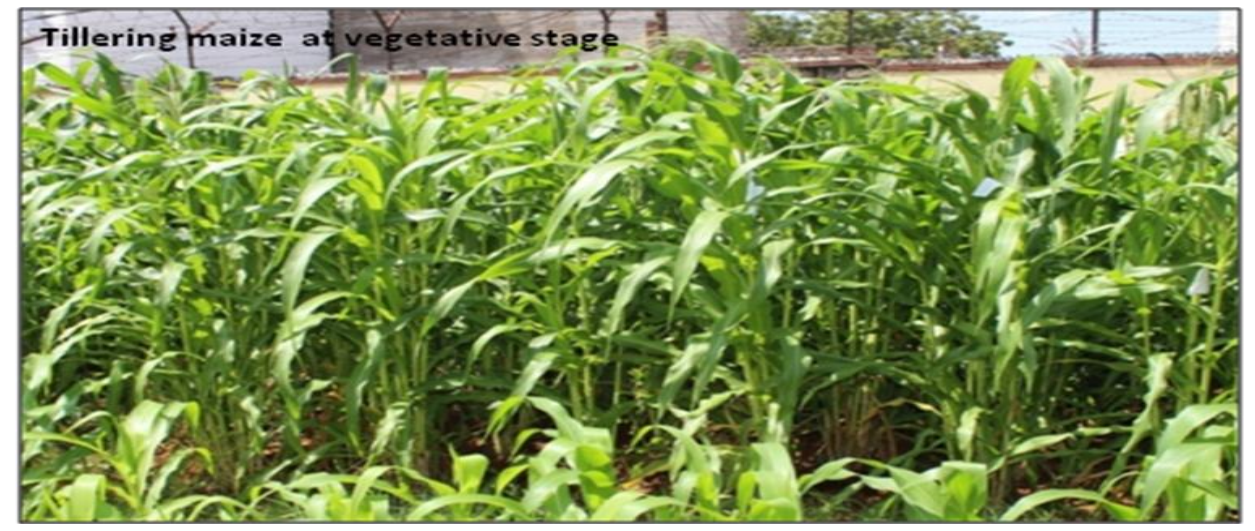

For number of leaves, the superiority of tillering maize was $34.1,315.8 \%, 423.7$ over teosinte, African tall and harsha respectively. Similarly for no. of cobs the superiority of CRTM-2 over African tall and harsha was 2350.0 and $2086.0 \%$ respectively. However there was decrease in number of cobs in CRTM-2 (-53.0\%) compared to teosinte though the size of CRTM-2 cobs were significantly better than teosinte for both diameter and length while the cobs of teosinte are very small with very small and bitter seed. The superiority of tillering maize, CRTM-2 for tillering trait over the checks African tall and harsha and with maize type cobs and seed reveals it to be very potential innovative genotype.

The PCR amplification profile of checks/parents (teosinte, African tall and 
harsha) and CRTM-2 obtained with six ssr loci (Fig. 2) covered 160 alleles on the genomic DNA located on the chromosome 17. Furthermore allelic diversity for each loci varied greatly from one to another locus, while significant variation in allelic frequency was also observed in between parental lines and CRTM-2. The number of alleles ranged from 1-9 with an average of 4.44. In present study 59 polymorphic bands were observed from six ssr primers which yielded $90.76 \%$ polymorphism. Highest percentage of polymorphism was observed in bnlg 490 and bnlg 1346 (100\%). Total 6 monomorphic bands were observed, each 2 for umc-1546 and bnlg -589 while one for phi-116 and bnlg1178 .

The clustering pattern (Fig. 3) revealed the similarity between CRTM-2 and teosinte, African tall and harsha and confirmed that these three maize sub species were the parental lines for development of CRTM-2. The clustering of main clades and subclades revealed the inheritance pattern of the loci from parental lines to CRTM-2.

CRTM-2 can be source material for innovative concept of developing new tillering maize varieties with effective cobs for higher productivity of fodder, poultry feed and human food apart from industrial uses.

\section{References}

Casas SJF, Sánchez GJJ, Ramírez DJL, Ron
PyS, Montes HJ. 2001. Rendimiento y sus componentes en retrocruzas maízteocintle. Revista Fitotecnia Mexicana 24, $17-26$.

Cohen JI, Galinat WC. 1984. Potential use of alien germplasm for maize improvement.

Crop Science 24, 1011-1015.

Doyle, J.J and Doyle J.L. Isolation of plant DNA from fresh tissue. Focus, v.12, p.13-15, 1990

Jaccard, P. 1901 Etude comparative de la distribution florale dans une portion desalpes et des jura, Bull. Soc. Vaud. Sci. Nat. 37: 547-579.

Murray, H.G and W.F. Thompson, 1980 Rapid isolation of high molecular weight plant DNA, Nucleic. Acids. Res. 8: 4321-4325.

Perrier X., A. Flori and F. Bonnot, 2003 Data analysis methods, in: P. Hamon, $M$. Seguin, X. Perrier, J.C. Glaszmann (Eds.), Genetic Diversity of Cultivated Tropical Plants, Enfield, Science Publishers, Montpellier, pp. 43-76.

Reeves RG. 1950. The use of teosinte in the improvement of corn inbreds. Agronony Journal 42,248-251.

Weber, A. L., William H.B., Rucker J., Baltazar M.B., J. de Jesus sanchezgonzalez, Feng P., Buckler E.S. and Doebley J., 2008 The Genetic Architecture of Complex Traits in Teosinte (Zea mays ssp. parviglumis): New Evidence From Association Mapping Genetics, 180: 1221-1232

\section{How to cite this article:}

Jyothi Lakshmi, N., P. Raghuram Reddy, Amol Patil, M. Vanaja, K. Salini, B. Sarkar, S.S. Shishodia, S.K. Yadav, V. Maruthi, M. Maheswari, K. Sammi Reddy and Ravindra Chary, G. 2019. CRTM-2: Maize with Effective Tillering Trait. Int.J.Curr.Microbiol.App.Sci. 8(05): 1320-1327. doi: https://doi.org/10.20546/ijcmas.2019.805.150 